\title{
PRAKTEK PENENTUAN ARAH KIBLAT \\ BAGI PANITIA PEMBANGUNAN MASJID AT-TAWWABIN MANGKUYUDAN RT 01/04 NGABEYAN KARTASURA SUKOHARJO
}

\author{
Harun dan Ruswa Darsono \\ Program Studi Muamalat Jurusan Syari' ah Fakultas Agama Islam \\ Universitas Muhammadiyah Surakarta \\ harunmh67@gmail.com \& ruswadarsono@yahoo.com
}

\begin{abstract}
Member Of Mangkuyudan RT 01/04 mostly is majority religion islam having strong commitment to practice its(the religion teaching correctly as according to manual al-Qur'an and al-Hadits. Constraint faced by them is Pertama, has not there are a place to do religious service sholat fulfilling clauses figh, that is form of building mosque which its (the position towards direction of direction which tepatKedua, most of member of moslem mangkuyudan RT 01/04 still a few its(the knowledges about direction of direction according to calculation science falaq. Third, has not there is member of mangkuyudan RT 01/04 becoming place to enquire to religion problems, especially determination problem of direction of correct direction. Based on reasoning of this problem, hence some of member of sympathizer publics Muhammadiyah wishful to build mosque and formed [by] development committee of mosque'. As for becoming problems is development committee of mosque still be civil in the case of direction of correct direction and precise. They is there are strong desire to know about knowledge of direction of correct direction. Constraint faced by them is there is no institute or institution is its(the desire response. As according to problems is upper, hence solution done is perform [a] training of practice of determination of direction of direction with Resource person from the expert, in this case is Study Program Muamalat Islamic Religion faculty UMS. Determination Method of direction of direction applied in devotion of this public is apply object shadow because of sunshine. This model can be done by the way of determination with calculating difference Azimuth the sun and Kiblat of direction.Result practice of calculation determination of direction of direction in Mangkuyudan RT 01/04 Ngabeyan Kartasura Sukoharjo is Selisih Azimuth Kiblat ( Direction of Direction Counted - direction of Shadow) ) 294 33'33,84' - 291 47' $58^{\prime \prime}=+1^{\circ} 45^{\prime} 35,84^{\prime \prime}$. On the basis of inferential this that direction of its (the direction is $+1^{\circ} 45^{\prime} 35,84^{\prime \prime}$ dari shadow or $1^{\circ} 45^{\prime} 35,84^{\prime \prime}$ right side shadow. Positive impact of activity of devotion at public is development committee of mosque ( member of sympathizer moslem Muhammadiyah) Mangkuyudan Rt 01/04, gets addition of theology ( though has not is optimal), especially determination of direction of correct qiblat as according to science falaq and they motivat is strong to be more deepens the science.
\end{abstract}

Kata kunci: arah kiblat, azimuth, bayangan matahari 


\section{PENDAHULUAN}

\section{Analisis Situasi}

Masjid adalah sentral tempat melakukan ibadah sebagai perwujudan penghambaan diri kepada Allah. Salah satu bentuk penghambaan diri kepada Allah adalah sholat. Sholat adalah bentuk ibadah yang penting, bahkan termasuk amal perbuatan manusia yang pertama kali dihisap besok dihari kiamat. Oleh sebab itu, dalam melakukan sholat perlu diperhatikan syarat keabsahannya. Jumhur Ulama telah menetapkan bahwa menghadap kearah kiblat ketika melakukan shalat merupakan syarat syahnya shalat.Para Ulama telah sepakat bahwa hukum menghadap kearah kiblat dalam melakukan shalat adalah wajib (Sayid Sabiq, 1973 :308,Hasbi Ash-Shiddeqie, 1993; 392), berdasarkan dalil hukum :

a. Firman Allah Swt. dalam Surat alBaqarah , 2 : 144 :

Sungguh Kami (sering) melihat mukamu menengadah ke langit, maka sungguh Kami akan memalingkan kamu ke kiblat yang kamu sukai. Palingkanlah mukamu ke arah Masjidil Haram. Dan di mana saja kamu berada, palingkanlah mukamu ke arahnya. Dan sesungguhnya orang-orang (Yahudi dan Nasrani) yang diberi Al Kitab (Taurat dan Injil) memang mengetahui, bahwa berpaling ke Masjidil Haram itu adalah benar dari Tuhannya; dan Allah sekali-kali tidak lengah dari apa yang mereka kerjakan.

b. Hadits Nabi Saw :

“.... Jika kamu berdiri untuk shalat sempurnakan wudhumu kemudian menghadaplah ke qiblat lalu takbirlah ...." (Imam Bukhori, 1998 ; hadits No.5782).

c. Hadits Nabi Saw :

Dari Al-Baraa' dia berkata kami shalat bersama Rasuulullah SAW menghadap Baitul Maqdis enam belas bulan atau tujuh belas bulan, kemudian kami dipalingkan menghadap ka'bah (Imam Muslim, 1998 ;819).

Warga Mangkuyudan RT 01/04 sebagian besar adalah pendatang dan mayoritas pemeluk agama Islam yang mempunyai komitmen kuat untuk mengamalkan ajaran agamanya secara benar sesuai dengan tuntunan al-Qur'an dan al-Hadits. Kendala yang dihadapi oleh mereka adalah Pertama, belum ada tempat untuk melakukan ibadah sholat yang memenuhi persyaratan fiqh, yaitu bentuk bangunan Masjid yang posisinya menuju arah kiblat yang tepat. Kedua, sebagian besar warga muslim mangkuyudan RT 01/04 masih sedikit pengetahuannya tentang arah kiblat yang tepat dan benar menurut perhitungan ilmu falaq. Ketiga, belum ada warga mangkuyudan RT 01/04 yang menjadi tempat bertanya terhadap permasalahan agama, terutama maasalah penentuan 1 Ramadhan, 1 Syawal (Idul Fitri) dan 10 Dzulhijjah (Idul Adha), termasuk tentang hal ihwal arah kiblat.

\section{Perumusan Masalah}

Berdasar identifikasi permasalahan tersebut, dapat dirumuskan masalahnya sebagai berikut:

a. Panitia Pembangunan Masjid Mangkuyudan RT 01/04 Desa Ngabeyan Kecamatan Kartasura masih awam.

b. Mereka ada keinginan kuat untuk mengetahui tentang pengetahuan arah kiblat yang benar

c. Kendala yang dihadapi mereka adalah tidak ada lembaga atau institusi yang merespon keinginannya.

\section{Tinjauan Pustaka}

a. Hukum Menghadap Arah Kiblat Jumhur Ulama telah menetapkan bahwa menghadap kearah qiblat ketika melakukan shalat merupakan syarat syahnya shalat.Para Ulama telah sepakat 
bahwa hukum menghadap kearah kiblat dalam melakukan shalat adalah wajib, kecuali dalam keadaan-keadaan tertentu. Hukum wajib menghadap arah kiblat ketika dalam melakukan shalat didasarkan pada dalil-dalil hukum sebagai berikut:

1) Firman Allah Swt dalam surat alBaqarah, 2 ; 144:

Sungguh Kami (sering) melihat mukamu menengadah ke langit, maka sungguh Kami akan memalingkan kamu ke kiblat yang kamu sukai. Palingkanlah mukamu ke arah Masjidil Haram. Dan di mana saja kamu berada, palingkanlah mukamu ke arahnya. Dan sesungguhnya orang-orang (Yahudi dan Nasrani) yang diberi Al Kitab (Taurat dan Injil) memang mengetahui, bahwa berpaling ke Masjidil Haram itu adalah benar dari Tuhannya; dan Allah sekali-kali tidak lengah dari apa yang mereka kerjakan.

2) Hadits Nabi Saw :

“.... Jika kamu berdiri untuk shalat sempurnakan wudhumu kemudian menghadaplah ke qiblat lalu takbirlah ... “

3) Hadits Nabi Saw :

Dari Al-Baraa' dia berkata kami shalat bersama Rasuulullah SAW menghadap Baitul Maqdis enam belas bulan atau tujuh belas bulan, kemudian kami dipalingkan menghadap ka'bah.

\section{b. Definisi Kiblat}

Sebagaimana telah diuraikan dimuka, perihal kewajiban menghadap kiblat para ulama sudah bersepakat karena jelasnya dalil yang menjadi sandaran. Akan tetapi, ketika sampai kepada pertanyaan, "Menghadap kiblat itu seperti apa?" terdapat perbedaan diantara para ulama. Apabila kita telusuri
Nash al-Qur'aan dan Sunnah Nabi SAW, terdapat tiga definisi kiblat, yakni Ka'bah, Masjidil-Haram, dan Arah Pendekatan (atau kira-kira) ke Masjidil Haram.

1) Kiblat adalah Ka'bah:

Dalam sebuah hadits yang termuat dalam Shahiih Al-Bukhari dari Ibnu Abbas, Nabi SAW menyatakan bawa Qiblat adalah Ka'bah:

Ibnu Abbas berkata," Bahwasanya Nabi SAW masuk kedalam Baitullah, Nabi berdoa di sudut-sudutnya dan tidak shalat. Kemudian beliau keluar, lalu shalat dua rakaat dimuka Ka'bah, seraya bersabda :'Inilah Kiblat'”.

2) Kiblat adalah Masjidil Haram

Al-Qur'aan surah al-Baqarah, $2 ; 149$ dan 150 menyatakan bahwa qiblat adalah Masjidil-Haram.

Dan dari mana saja kamu ke luar, maka palingkanlah wajahmu ke arah Masjidil Haram; sesungguhnya ketentuan itu benar-benar sesuatu yang hak dari Tuhanmu. Dan Allah sekali-kali tidak lengah dari apa yang kamu kerjakan.

Dan dari mana saja kamu keluar, maka palingkanlah wajahmu ke arah Masjidil Haram. Dan di mana saja kamu (sekalian) berada, maka palingkanlah wajahmu ke arahnya, agar tidak ada hujjah bagi manusia atas kamu, kecuali orang-orang yang zalim di antara mereka. Maka janganlah kamu takut kepada mereka dan takutlah kepada-Ku. Dan agar Kusempurnakan ni'mat-Ku atasmu, dan supaya kamu mendapat petunjuk.

Penulis, pada definisi qiblat yang kedua ini, mengambil istilah "Kiblat adalah Masjidil Haram" bukannya "Kiblat adalah Arah Masjidil Haram" 
karena kata Syathara selain memiliki arti arah juga memilki arti tengahtengah dari kata kerja Syathara yang memiliki arti membagi dua sama besar.

3) Kiblat adalah Arah Pendekatan ke Masjidil Haram

Dari Abu Hurairah r.a beliau berkata, "Nabi SAW bersabda:'Diantara timur dan barat terletak Qiblat"'.

Hadits semakna juga diriwayatkan dalam Sunan Tirmidzy dari bermacam jalur sanad). Menurut Turmudzy hadits ini hasan shahih.

Menurut As-Sayyid Sabiq : ini adalah untuk penduduk kota Madinah dan orang yang sejurusan dengan mereka. Penulis mengambil istilah arah pendekatan atau perkiraan atau arah kasar bukan arah yang tepat dibandingkan dengan Syathara yang berarti arah tepat.

4) Bagaimana Sikap Kita?

Allah berfirman:

17. Dan orang-orang yang menjauhi thaghut (yaitu) tidak menyembahnya dan kembali kepada Allah, bagi mereka berita gembira; sebab itu sampaikanlah berita itu kepada hamba-hamba-Ku, 18. yang mendengarkan perkataan lalu mengikuti apa yang paling baik di antaranya. Mereka itulah orangorang yang telah diberi Allah petunjuk dan mereka itulah orang-orang yang mempunyai akal.

Nabi shallallahu 'alaihi wa sallam bersabda,

Arti kamus:

Telah menceritakan kepada kami Abdus Salam bin Muthahhar berkata, telah menceritakan kepada kami Umar bin Ali dari Ma'an bin Muhammad Al Ghifari dari Sa'id bin Abu Sa'id Al Maqburi dari Abu Hurairah bahwa Nabi shallallahu 'alaihi wasallam bersabda: "Sesungguhnya agama itu mudah, dan tidaklah seseorang mempersulit agama kecuali dia akan dikalahkan (semakin berat dan sulit). Maka berlakulah lurus kalian, mendekatlah (kepada yang benar) dan berilah kabar gembira dan minta tolonglah dengan Al Ghadwah (berangkat di awal pagi) dan arruhah (berangkat setelah zhuhur) dan sesuatu dari ad-duljah ((berangkat di waktu malam) ".

Atau Arti yang sudah disesuaikan dengan berbagai keterangan tambahan dan penjelasan berkenaan hadits ini: "Sesungguhnya agama itu mudah. Tidak ada seorangpun yang membebani dirinya di luar kemampuannya kecuali dia akan dikalahkan. Hendaklah kalian melakukan amal dengan sempurna (tanpa berlebihan dan menganggap remeh). Jika tidak mampu berbuat yang sempurna (ideal) maka lakukanlah yang mendekatinya. Dan berilah kabar gembira. Manfaatkanlah waktu pagi dan waktu setelah matahari tergelincir serta waktu di akhir malam."

Perintah nabi kepada sahabat Wabr bin Yuhanas al Khazaa'iy tentang membangun masjid di Shana'a kearah kiblat Berkata Wabir bin Yuhanas alKhuzaa'iy, "Berkata kepadaku Rasuulullah,'Jika dibangun Masjid Shana'aa jadikan dia sebelah kanan sebuah gunung yang bernama Dlain' ". Dan ternyata dengan bantuan Google Earth, pendirian masjid dengan perintah hadits ini menunjukkan bahwa arah qiblat masjid dengan mengarah ke gunung Dhiin, tepat ke tengahtengah ka'bah.

c. Menentukan Arah Qiblat

Menentukan arah kiblat dari suatu tempat pada pengertian dasarnya adalah menentukan arah Ka'bah atau Masjidil 
Haram dari tempat tertentu tersebut. Ada dua model dalam penentuan tersebut, yakni: 1) Penentuan arah kiblat dengan bantuan penentuan arah acuan 2) Penentuan arah kiblat langsung tanpa bantuan penentuan arah acuan.

1) Penentuan Arah Kiblat Dengan Bantuan Penentuan Arah Acuan

Penentuan cara ini menghendaki urutan pekerjaan sebagai berikut: a) Mencari tahu lokasi tempat pengamatan (tempat kita ingin mengukur arah qiblat kita).Alat yang dapat digunakan sebagai bantuan adalah peta, perangkat Penerima GPS; b) Mencari tahu lokasi Ka'bah/Masjidil-Haram. Alat yang dapat digunakan sebagai bantuan adalah peta, perangkat Penerima GPS; c) Menghitung besar sudut arah Ka'bah/Masjidil-Haram dari Titik Pengamatan. Perhitungan menggunakan rumus 1 atau 2 pada sub judul E diatas. Pada tahap ini perlu diperhatikan besar sudut dari arah acuan apa (arah acuan dalam dalam pengertian). Rumus diatas dihitung dengan arah acuan Utara sejati; d) Mencari tahu Arah Acuan (arah acuan dalam kenyataan); e) Membandingkan besar sudut arah qiblat dengan arah acuan; f) Mengukur besar sudut arah qiblat dari arah acuan.Pada tahap ini dapat digunakan bantuan teodolit, busur derajat, dan segitiga siku dengan mengitung tangen sudut lancipnya; g) Membandingkan langkah; h) dengan posisi dinding masjid;

i) Mengukur dan menetapkan besar sudut arah qiblat dari dinding masjid.

2) Penentuan Arah Kiblat Tanpa Bantuan Penentuan Arah Acuan

Penentuan arah qiblat dengan cara ini lebih sederhana dibanding cara G.1. Ada beberapa cara yang dapat dipakai untuk penentuan ini. Cara pertama adalah dengan bantuan peta, dan yang kedua dengan bantuan bayangan matahari atau bulan.

a) Penentuan Dengan Bantuan Peta Peta yang banyak beredar adalah peta bumi yang merupakan proyeksi bumi bulat kedalam "bentuk tabung yang 'dibuka digelarkan', yang dalam istilah pemetaan disebut proyeksi mercator. Proyeksi ini memberikan semua lintang dan bujur dalam bentuk garis lurus dengan panjang yang sama untuk garis lintangnya. Padahal pada kenyataannya garis bujur melengkung dan menyatu dikedua kutub, sedangkan garis lintang melengkung dengan panjang yang makin memendek dari khatulistiwa menuju kutub.

Penarikan garis lurus untuk mendapatkan arah kiblat dengan bantuan peta jenis ini dari posisi tertentu akan mendapatkan hasil yang sangat salah ${ }^{10}$. Contohnya garis lurus ac yang berawal dari Canada berakhir di Makkah, menunjukkan arah kiblat Canada adalah tenggara. Padahal, jarak terdekat dari Canada ke Makkah adalah lewat Timur Laut. Jadi penggunaan peta jenis ini untuk "Penentuan Arah Qiblat" TIDAK DISARANKAN.

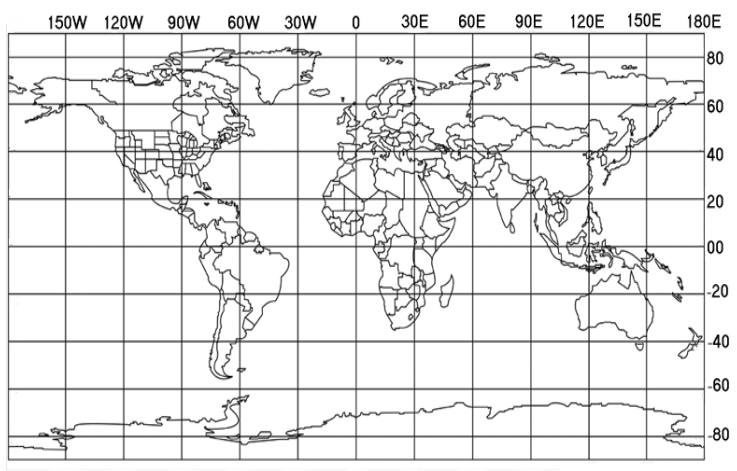

Gb.1. Peta Dunia Proyeksi Mercator dengan garis ac 
Gb. 2. Garis ac pada gb 4 dilihat pada peta digital Google Earth dan perbandingannya dengan jarak terpendek

Jenis peta yang paling mendekati kenyataan bentuk bumi adalah Globe, yakni peta dalam bentuk miniatur bumi berbentuk bulat. Dan, termasuk kedalam peta yang paling mendekati kenyataan adalah peta digital seperti Google Earth dan Google Maps dari Google, World Wind dari NASA, dari Microsoft, dan Yahoo Maps dari Yahoo. Gambar 5 menunjukkan arah "yang salah" menurut garis ac dan arah "yang seharusnya" menurut jarak terpendek. Jadi, peta jenis kedu ini dapat digunakan membantu kita dalam menentukan arah qiblat, khususnya peta digital semacam Google Earth.

b) Penentuan Dengan Bantuan Bayangan Matahari

Bayangan benda oleh karena sinar matahari dapat digunakan untuk menentukan arah qiblat. Terdapat tiga mecam penentuan sehubungan dengan pemanfaatan bayangan matahari ini. Ketiganya adalah: 1) Penentuan ketika Matahari di sekitar Zenith Ka'bah. 2) Penentuan ketika Matahari di sekitar Nadir Ka'bah 13 Jan 2010 pk 21 30 UT, dan 28 Nov 2010 pk 21 09 UT. 3) Penentuan ketika bayangan benda searah atau berlawanan arah qiblat. 4) Penentuan dengan menghitung selisih Azimuth Matahari dan Arah Qiblat.

c) Penentuan ketika Matahari di sekitar Zenith Ka'bah.

Ketika Matahari berada $d i$ Zenith Ka'bah, sinarnya akan membentuk bayangan yang menjauhi Ka'bah, sehingga arah dari ujung bayangan ke pangkal baangan merupakan arah ke ka'bah/kiblat. Dalam tiap satu tahunnya matahari berada disekitar zenith Ka'bah dua kali, yaitu ketika matahari "sedang menuju utara" beberapa hari sebelum dan sesudah tanggal 28 Mei sekitar pukul 16.18 WIB, dan ketika "sedang balik ke selatan" dari perjalanan tahunannya dari khaulistiwa-garis balik utara-khatulistiwa-garis balik selatan-khatulistiwa lagi, yakni beberapa hari sebelum dan sesudah tanggal 15 Juli pada sekitar pukul 16.27 WIB.

Menurut penelitian penulis, dua hari sebelum dan dua hari sesudah tanggal-tanggal tersebut masih bisa dipakai untuk pengukuran arah qiblat jika kita masih menerima kesalahan hingga $1 / 2$ derajat saja. Jika kita hanya mentolerir kesalahan hingga 15 menit sudut maka 3 hari yakni sebelum, sesudah dan pada tanggal-tanggal 
tersebut diatas pengukuran dapat dilakukan. Dan waktu pengukuran dalam tiap-tiap hari pengukurannya bisa dilakukan mulai menit kedua sebelum menit tersebut diatas dan hingga menit kedua sesudahnya.

Lalu, bagaimana caranya? Cara-nya adalah: 1) Sediakan tongkat dengan diameter $1 \mathrm{~cm}$ dan panjang $50 \mathrm{~cm}$. 2) ikat sebuah pemberat seperti batu atau besi pada benang dengan panjang secukpnya, lalu pegang dan gantung pemberat dengan tali tersebut. 3) letakkan atau tancapkan tongkat berdiri tegak mengikuti tegak dan lurusnya tali berpemberat tadi (tali dan pemberat tersebut dinamakan unting-unting). 4) cocokkan pencatat waktu anda dengan menelpon Telkom lokal 103 atau dengan waktu pada pesawat GPS. 5) Perhatikan bayangan tongkat saat yang bertepatan dengan waktu pengukuran. 6) Arah Qiblat adalah arah dari ujung bayangan ke pangkal bayangan.

Penentuan arah qiblat dengan cara ini memiliki kekurangan yakni pengukuran hanya dapat dilakukan pada daerahdaerah yang berselisih waktu kurang dari 6 jam di sebelah barat dan timur Makkah, atau daerahdaerah yang beada dalam belahan bumi yang sama dengan Makkah saat matahari mengalami transit di Makkah/ka'bah. Diluar itu tidak dapat dilakukan karena matahari belum terbit atau sudah terbenam. Juga di daerah-daerah yang hampir ketinggian matahari saat waktu pengentuan arah qiblat masih/sudah rendah sehingga sulit mendapatkan bayangannya. Dan, tentu saja syarat yang pokok, adalah sinar matahari tidak terhalang apapun saat dilakukan penentuan pada lokasi penentuan tersebut.

d) Penentuan ketika Matahari di sekitar Nadir Ka'bah

Penentuan dengan cara ini dilakukan untuk daerah-daerah pada belahan berseberangan dengan Belahan Makkah atau saat Makkah sedang mengalami tengah malam. Saatnya adalah ketika Matahari berada tepat disekitar nadir Ka'bah. Kejadian ini berlangsung tiap sekitar tanggal 13 Januari pukul 21.30 UT dan 28 November 21.09 UT. Lama jangka waktu dan cara penentuannya sama dengan yang dilkukan pada penentuan ketika matahari di sekitar zenith ka'bah.

e) Penentuan ketika bayangan benda searah atau berlawanan arah dengan arah kiblat

Di daerah-daerah tertentu, dapat terjadi keadaan matahari, pengamat dan ka'bah berada dalam bidang yang sama pada bidang lingkaran besar bola langit. Keadan ini terjadi saat posisi matahari saat memiliki azimuth yang sama dengan sudut arah kiblat dari satu tempat atau ketika azimuth matahari berbeda 180 derajat dari arah kiblat suatu tempat. Saat-saat seperti ini pad suatu daerah dapat terjadi setiap hari sepanjang tahun, akan tetapi pada daerah-daerah yang lain hanya terjadi dalam beberapa hari saja. Dengan Perangkat Lunak yang sudah beredar, waktu-waktu 
untuk penentuan arah kiblat ini dapat diperoleh dengan mudah untuk setiap daerah yang kita kehendaki.

f) Penentuan Menggunakan Selisih Azimuth Matahari dan Arah kiblat

Penentuan model ini adalah yang paling fleksibel untuk sembarang daerah dan sembarang waktu, tentu saja dengan syarat adanya sinar matahari di tempat penentuan. Cara ini pada prinsipnya adalah memenggunakan arah bayangan benda oleh matahari digunakan sebagai acuan untuk menentukan besarnya sudut yang ditambah atau dikurangkan terhadap sudut bayangan benda tersebut untuk mendapatkan arah kiblat. Sudut bayangan benda diketahui dari azimuth matahari yang sudah diketahui lewat perhitungan. Dengan definisi sudut bayangan adalah arah ujung bayangan dihitung dari pangkal bayangan dibandingkan terhadap arah utara, maka arah bayangan adalah nilai azimuth +180 derajat. Cara penentuannya adalah sebagai berikut: 1) Cari tahu posisi tempat pengamatan/penentuan, yakni lintang dan bujurnya. 2) Cari tahu posisi lintang dan bujur Ka'bah/ Masjidil Haram/Makah. 3) Hitung sudut arah Kiblat dari tempat penentuan. 4) Tentukan/ pilih waktu untuk penentuan arah kiblat. 5) Hitung azimuth matahari saat waktu penentuan arah kiblat yang telah dipilih. 6) Hitung selisih arah kiblat dengan arah bayangandengan ketentuan kurangi sudut Arah kiblat dengan Arah Bayangan ([sudut arah kiblat] - [Azimuth

Matahari+180]), perhatikan tanda hasil pengurangannya plus atau minus. Kita namakan saja hasilnya sebagai selisih azimuthkiblat. 7) Lakukan Pengamatan pada waktu yang telah dipilih. 8) Perhatikan dan catat arah bayangan yang terjadi. 9) arah qiblat adalah arah sebesar selisih azimuth-kiblat kearah kiri dari ujung bayangan jika [selisih azimuth-qiblat berharga negatif], atau kearah kanan jika [selisih azimuth-kiblat berharga positif],

\section{Tujuan dan Manfaat}

Sesuai dengan permasalahan tersebut, maka dengan kegiatan pengabdian masyarakat ini bertujuan dapat menambah pengetahuan agama yang berkaitan dengan penentuan arah kiblat yang tepat bagi Panitia Pembangunan Masjid (simpatisan Muhammadiyah) di Mangkuyudan RT 01/04 Desa Ngabeyan Kecamatan Kartasura.

Adapun manfaat dari kegiatan pengabdian ini, warga muslim Mangkuyudan RT 01/04 Desa Ngabeyan dapat melakukan Ibadah Sholat secara sah yaitu posisi sholat menghadap arah kiblat yang tepat.

\section{METODE PELAKSANAAN}

\section{Indentifikasi Masalah}

Sesuai dengan analisis situasi diatas, maka dapat diindentifikasi masalah sebagai berikut: 1) Panitia Pembangunan Masjid Mangkuyudan RT 01/04 Desa Ngabeyan Kecamatan Kartasura masih awam. 2) Mereka ada keinginan kuat untuk mengetahui tentang pengetahuan arah kiblat yang benar. 3) Kendala yang dihadapi mereka adalah tidak ada lembaga atau institusi yang merespon keinginannya.

Solusi yang dilakukan adalah mengadakan Pelatihan Praktek Penentuan Arah Kiblat dengan Nara Sumber dari para pakar 
Fakultas Agama Islam UMS Program Studi Muamalat (Syari' ah).

\section{Metode Pengabdian}

Metode pengabdian yang dilaksanakan adalah: 1) Pembekalan materi dalam bentuk ceramah dan dialoq interaktif. 2) Pelatihan praktek penentuan arah kiblat di lokasi pembangunan Masjid. Metode atau teori penentuan arah kiblat Ada dua model dalam penentuan tersebut, yakni : 1) Penentuan arah qiblat dengan bantuan penentuan arah acuan. 2) Penentuan arah qiblat langsung tanpa bantuan penentuan arah acuan.

Model penentuan arah kiblat dalam kegiatan pengabdian masyarakat ini menggunakan model kedua, yaitu penentuan arah kiblat langsung tanpa bantuan penentuan arah acuan. Penentuan arah kiblat dengan cara ini lebih sederhana dibanding model pertama . Ada dua cara yang dapat dipakai untuk penentuan arah kiblat ini. Cara pertama adalah dengan bantuan peta, dan yang kedua dengan bantuan bayangan benda karena sinar matahari atau bulan. Dari dua cara ini, kegiatan pengabdian lebih memilih cara dengan bantuan bayangan benda karena sinar matahari.

Penentuan arah kiblat dengan bayangan benda oleh karena sinar matahari dapat dilakukan dengan empat cara, yaitu: 1) Penentuan ketika Matahari di sekitar Zenith Ka'bah. 2) Penentuan ketika Matahari di sekitar Nadir Ka'bah 13 Jan 2010 pk 2130 UT, dan 28 Nov 2010 pk 2109 UT. 3) Penentuan ketika bayangan benda searah atau berlawanan arah kiblat. 4) Penentuan dengan menghitung selisih Azimuth Matahari dan Arah Kiblat.

Diantara empat cara penentuan arah kiblat dengan pemanfaatan bayangan matahari yang digunakan dalam kegiatan pengabdian ini adalah cara yang ke empat yaitu penentuan dengan menghitung selisih Azimuth matahari dan Arah Kiblat.
Penentuan model ini adalah yang paling fleksibel untuk sembarang daerah dan sembarang waktu, tentu saja dengan syarat adanya sinar matahari di tempat penentuan. Cara ini pada prinsipnya adalah meenggunakan arah bayangan benda oleh matahari digunakan sebagai acuan untuk menentukan besarnya sudut yang ditambah atau dikurangkan terhadap sudut bayangan benda tersebut untuk mendapatkan arah kiblat. Sudut bayangan benda diketahui dari azimuth matahari yang sudah diketahui lewat perhitungan. Dengan definisi sudut bayangan adalah arah ujung bayangan dihitung dari pangkal bayangan dibandingkan terhadap arah utara, maka arah bayangan adalah nilai azimuth+180 derajat.

Cara penentuannya adalah sebagai berikut: 1) Cari tahu posisi tempat pengamatan/ penentuan, yakni lintang dan bujurnya. 2) Cari tahu posisi lintang dan bujur Ka'bah/ Masjidil Haram/Makah. 3) Hitung sudut arah Kiblat dari tempat penentuan. 4) Tentukan/ pilih waktu untuk penentuan arah kiblat. 5) Hitung azimuth matahari saat waktu penentuan arah kiblat yang telah dipilih. 6) Hitung selisih arah qiblat dengan arah bayangan dengan ketentuan kurangi sudut Arah Kiblat dengan Arah Bayangan ([sudut Arah Kiblat] - [Azimuth Matahari+180]), perhatikan tanda hasil pengurangannya plus atau minus. Kita namakan saja hasilnya sebagai selisih azimuth-kiblat. 7) Lakukan Pengamatan pada waktu yang telah dipilih. 8) Perhatikan dan catat arah bayangan yang terjadi. 9) arah kiblat adalah arah sebesar selisih azimuth-kiblat kearah kiri dari ujung bayangan jika [selisih azimuth-kiblat berharga negatif], atau kearah kanan jika [selisih azimuth-kiblat berharga positif],

\section{HASIL DAN PEMBAHASAN}

Praktek penentuan arah kiblat pada pembangunan Masjid at-Tawwabin diselenggarakan atas inisiatif warga muslim simpatisan Muhammadiyah di Mangkyudan 
RT 01/04 Ngabeyan Kartasura yang sekaligus sebagai penitia pembangunan. Harapan mereka dengan adanya pengabdian Masyarakat yang dilakukan oleh nara sumber dari FAI UMS Program Studi Syari'ah dapat memberikan bekal ilmu pengetahuan masalah keislaman khususnya tentang arah kiblat bagi calon jama' ah shalat atau warga muslim Mangkuyudan RT01/04 Desa Ngabeyan.

Pengabdian Masyarakat dilaksanakan pada hari Minggu tanggal 3 januari 2011 dimulai jam 07.20 sampai jam 10.00 di Lokasi Pembangunan Masjid at-Tawwabin, Mangkuyudan RT 01/04 Desa Ngabeyan yang seyogyanya diikuti 0leh 15 orang panitia pembangunan Masjid, namun yang hadir aktif mengikuti praktek perhitungan arah kiblat adalah empat orang panitia (warga muslim dari simpatisan Muhammadyah).

Metode atau teori penentuan arah kiblat Ada dua model dalam penentuan tersebut, yakni: 1) Penentuan arah kiblat dengan bantuan penentuan arah acuan. 2) Penentuan arah kiblat langsung tanpa bantuan penentuan arah acuan.

Metode Praktek penentuan arah kiblat dalam pengabdian masyarakat ini dengan model kedua yaitu penentuan arah kiblat langsung tanpa bantuan penentuan arah acuan. Penentuan arah kiblat dengan cara ini lebih sederhana dibanding model pertama . Ada dua cara yang dapat dipakai untuk penentuan arah kiblat ini. Cara pertama adalah dengan bantuan peta, dan yang kedua dengan bantuan bayangan benda karena sinar matahari atau bulan. Dari dua cara ini, kegiatan pengabdian lebih memilih cara dengan bantuan bayangan benda karena sinar matahari.

Penentuan arah kiblat dengan bayangan benda oleh karena sinar matahari dapat dilakukan dengan empat cara, yaitu: 1) Penentuan ketika Matahari di sekitar Zenith Ka'bah.[2] Penentuan ketika Matahari di sekitar Nadir Ka'bah 13 Jan 2010 pk 2130 UT, dan 28 Nov 2010 pk 2109 UT. [3]
Penentuan ketika bayangan benda searah atau berlawanan arah kiblat. [4] Penentuan dengan menghitung selisih Azimuth Matahari dan Arah Kiblat.

Diantara empat cara penentuan arah kiblat dengan pemanfaatan bayangan matahari yang digunakan dalam kegiatan pengabdian ini adalah cara yang ke empat yaitu penentuan dengan menghitung selisih Azimuth matahari dan Arah Kiblat.

Metode Pengukuran Arah Kiblat "Selisih Azimuth Bayangan Matahari"adalah salah satu metode dalam mengukur/menentukan arah kiblat. Metode ini berbasis pengukuran bayangan benda oleh sinar matahari.

Pemahaman dasar metode ini adalah bahwa posisi matahari pada setiap saat dapat diketahui. Matahari dengan sinarnya yang memancar ke permukaan bumi, bila mengenai benda akan menghasilkan bayangan. Dengan mengetahui posisi matahari akan diketahui pula azimuthnya. Dan, dengan mengetahui azimuth matahari kita akan mengetahui pula arah bayangan benda oleh sinar matahari tersebut. Dalam hal ini benda dimaksud adalah benda kecil panjang dalam posisi tegak. Apabila kita sudah mengetahui - melalui perhitungan - arah kiblat dari/di suatu tempat pengamatan, maka dengan mengamati arah bayangan matahari kita dapat mengetahui arah qiblat dari menghitung selisih arah bayangan dan arah kiblat.

Posisi matahari diketahui melalui perangkat lunak ephemeris maupun perangkat lunak astronomi secara umum dengan ketelitian yang dapat kita pilih dari perangkat lunak yang digunakan. Arah kiblat dapat diketahui dari mengetahui posisi koordinat geografis tempat pengamatan/ pengukuran dan posisi koordinat geografis Masjid al-Haram/Ka'bah dengan menghitungnya memakai bantuan rumus segitiga bola yang sudah ada.

Posisi koordinat geografis Ka'bah diketahui dari banyak sumber data yang sudah ada, sedangkan posisi koordinat 
geografis tempat pengamatan diketahui melalui pesawat penerima GPS, atau perangkat lain seperti Peta 3D Google Earth. Kedua perangkat yang disebut terakhir memiliki ketelirtian yang sangat mencukupi untuk tujuan pengukuran ini. Sedangkan waktu saat pengambilan Bayangan digunakan waktu GPS yang dapat disamakan dengan waktu universal (UT) atau waktu mrerata sipil yang digunakan sehari-hari. Penggunaan waktu GPS ini memungkinkan pemakaian waktu yang akurat dan teliti.

Tabel 1. Hasil Kegiatan

Hasil dari perhitungan penentuan arah kiblat yang dilakukan pada hari Minggu tanggal 3 Januari 2011 bertepatan 28
Muharam $1432 \mathrm{H}$ dimulai jam $07.20 \mathrm{~s} / \mathrm{d}$ jam 10.00 di lokasi calon pembangunan Masjid At-Tawwabin Jalan Anata No.16 Mangkuyudan RT 01/04 Desa Ngabeyan Kartasura dapat dijelaskan atau ditentukan sebagai berikut:

Dampak positip dari hasil pengabdian masyarakat tersebut bagi panitia Pembangunan Masjid At-Tawwabin dari 15 orang RT 01/04 bagi panitia Pembangunan Masjid Attawwabin, terdapat 4 orang panitia sangat antusias sekali atau termotivasi kuat untuk mempelajari ilmu falaq (astronomi) bahkan ada permintaan kursus privat atau semacam tutorial yang rutin, sedang yang 11 orang nampaknya pasif dan tidak termotivasi, hal ini disebabkan disamping oleh faktor disiplin ilmu yang berbeda, juga dipengaruhi oleh faktor lingkungan, sosiologis dan faktor lainnya.

\section{SIMPULAN DAN SARAN}

\section{Simpulan}

Sebagai akhir laporan pengabdian pada Masyarakat, dapat diambil simpulan sebagai berikut:

a. Panitia Pembangunan Masjid atTawwabin mangkuyudan Rt 01/04, mendapat tambahan ilmu agama (meskipun belum optimal), khususnya penentuan arah qiblat yang tepat sesuai dengan ilmu falaq.

b. Panitia Pembangunan masjid yang menjadi simpatisan Muhammadiyah mangkuyudan RT 01/04 desa Ngabeyan terpanggil atau termotivasi kuat untuk lebih mendalami ilmu falak terkait dengan banyaknya pertanyaan yang muncul dari masyarakat tentang persoalan penentuan arah kiblat, tanggal 1 ramadhan, Idul Fitri ( 1 Syawal ) dan Idul Adha (10 Dzulhijjah),

Demikian, dua kesimpulan yang dapat diperoleh dari hasil kegiatan pengabdian masyarakat yang telah dilaksanakan oleh dua nara sumber dari Fakultas Agama Islam UMS. Mudah-mudahan ada manfaatnya, kelebihan dan kekuarangaanya, Nara sumber mohon maaf. 


\section{Saran-Saran}

Saran-saran yang dapat Nara Sumber sampaikan. Khususnya kepada pihak Lembaga Fakultas Agama Islam UMS dan masyarakat muslim pada umumnya, antara lain sebagai berikut:

a. Fakultas Agama Islam perlu membuat semacam Lembaga Biro Jasa Konsultan Masalah Keagamaan untuk melayani dan merospon aspirasi masyarakat yang selama ini berkembang berkaitan dengan kemajuan IPTEk dan Budaya.

b. Masyarakat Muslim khususnya warga mangkuyudan RT 01/04 Desa Ngabeyan meningkatkan kegiatan-kegiatan keIslaman dengan mengundang para pakar dari berbagai Lembaga akademik maupun lembaga sosial keagamaan.

Demikian saran yang dapat Nara Sumber sampaikan, mudahan-mudahan saran ini dapat direspon oleh yang bersangkutan dan ditindaklanjuti dengan bekerja sama dengan pihak atau lembaga-lembaga terkait.

\section{PERSANTUNAN}

Kesuseksan pengabdian ini atas dukungan semua pihak yang ikut terlibat dalam membantu peneliti. Oleh sebab itu, tidak lupa kami ucapkan benyak terima kasih, khususnya kepada :

1. Dr. Harun Joko Prayitno, M.Hum dan Drs. Suharjo, M.si selaku Ketua Lembaga Penelitian dan pengabdian pada masyarakat UMS yang telah memberikan persetujuan dan kesempatan nara sumberi melakukan pengabdian pada masyarakat

2. Drs. H.MA Fattah Santoso, M.Ag. selaku Dekan Fakultas Agama Islam yang telah memberikan persetujuan dan dorongan dalam melaksanakan pengabdian masyarakat

3. Sucipto. selaku Ketua Rukun Tetangga (RT 01/04) desa Ngabeyan yang telah memberikan motivasi fasilitas untuk diadakan pengabdian masyarakat dari nara sumber FAI-UMS.

4. Segenap Panitia Pembangunan Masjid atTawwabin yang telah merespon dengan baik atas pelaksanaan kegiatan Pengabdian pada Masyarakat.

Pengabdian Masyarakat ini, hasilnya masih jauh dari sempurna, oleh sebab itu besar harapan Nara Sumber atas kritik dan saran dari pembaca demi kebaikan atau kesempurnaan dan semoga pengabdian ini bermanfaat baik untuk kalangan akademik maupun masyarakat muslim pada umunya, dan

masyarakat muslim RT 01/04 Mangkuyudan Desa Ngabeyan Kartasura Sukoharjo. Amin.

\section{DAFTAR PUSTAKA}

Azhari,Susiknan, 2001. Ilmu Falak Teori dan Praktek, Lazuardi Yogyakarta.

Bukhori, Imam, 1998, Shahihul Bukhori, Riyadh ; Dar al-salam, Cet. I

Kerajaan Saudi Arabia, 1971, Al-Qur'an dan Terjemahnya, Saudi Arabia ;Khadim al-Haramain asy-Syarifain.

Muslim, Imam, 1998, Shohihul Muslim, Riyadh ; Dar al-Salam, Cet. I.

Rachim, Abd., 1983. Ilmu Falak, Liberty, Yogyakarta.

Sabiq, Sayyid,1973, Fikih Sunnah, Bandung ; al-Ma'arif, Cet. I

Ash Shiddiqi, Hasbi, 1993, Koleksi Hadits-hadits Hukum, Jakarta ; Yayasan Muhammad Hasbi Ash Shiddiqi, Cet 4, Jilid 2. 